\title{
Effect of Cryotherapy on Pain Perception and Wound Healing among Mothers with Episiotomy
}

\author{
Agalya Valkudai Somu1, Sathivel Arumugam², Vaijayanthimala Manogaran ${ }^{3}$ \\ ${ }^{1}$ Meenakshi College of Nursing, Meenakshi Academy of Higher Education and Research (Meenakshi University), \\ Mangadu, Chennai - 600 069, India \\ ${ }^{2}$ Faculty of Medicine, MAHSA University, Bandar Saujana Putra, 42610 Jenjarum, Selangor, Malaysia \\ ${ }^{3}$ Meenakshi College of Nursing, Meenakshi Academy of Higher Education and Research (Meenakshi University), \\ Mangadu, Chennai - 600 069, India
}

\begin{abstract}
The study focused on evaluating the effect of cryotheraphy on pain perception and wound healing among mothers with episiotomy at Sri Ramachandra Hospital, Chennai. The objectives formulated for this study were to - Evaluate the effect of cryotherapy on pain perception, effect of cryotherapy on wound healing, compare the pain perception and wound healing and to associate the demographic and clinical variables among mothers with episiotomy. The study population for the experimental and control group were selected by non-randomized convenient sampling technique. For experimental group, cryotherapy and for control group routine episiotomy care was given after pre-observation. Post-assessment was done immediately after, 1 hour, and 2 hours of application for both the groups. Totally each samples had five sitting in both the groups. The significant findings of the study were that majority of the samples were in the age group of 21-25 years, educated till high school. Epsiotomy pain perception reduced immediately, during first and second hour after cryotherapy at a highly significant level of $p<0.001$ among mothers with episiotomy in experimental group. Episiotomy pain perception increased at a significant level of $p<0.001$ immediately after routine episiotomy care for mothers with episiotomy in control group. There was significant reduction in episiotomy pain perception at a level of p<0.001 in first and second hour after routine episiotomy care in control group. Comparison of immediate and first hour episiotomy pain perception showed significant reduction at a level of $p<0.001$ among mothers with episiotomy in experimental group, whereas second hour episiotomy pain perception showed no significance. There was significant improvement in episiotomy wound healing in the experimental group at a level of $p<0.05$. There was highly significant association between habitance and immediate episiotomy pain perception at a level of $p<0.001$ and with first hour episiotomy pain perception at a level of $p<0.05$ during the first sitting.
\end{abstract}

Keywords: cryotherapy, pain perception, wound healing, mothers with episiotomy

\section{Introduction}

Birthing is normal, yet extraordinary process that has been with us from time immemorial. The moment of birth is both joyous and beautiful. The physiological transition from pregnancy to motherhood heralds an enormous change in each woman, physically and psychologically. Accompanying the physical changes are feelings of great intensity varying from excited anticipation to fearful expectancy. abour, the culmination of pregnancy, is a process with great psychological, social and emotional meaning for the mother and her family. In addition, the woman may experience stress and physical pain and danger may lurk around the corner. The midwife's skill and judgement are crucial factors in minimizing maternal trauma and ensuring a safe delivery. During childbirth women may sustain some degree of perineal trauma due to perineal tear or surgical cut called Episiotomy, the second most commonly performed surgery in maternity settings, next to cutting of the umbilical cord. Episiotomy is performed on millions of women every year. In some places like Japan and several Central European countries, virtually every woman who has her baby vaginally has an episiotomy. Episiotomy has been in practice since 1742, where a perineal incision was used to facilitate difficult deliveries. However, it did not become common until the early 1900s when the shift from home to hospital delivery occurred. The popularity of episiotomy among obstetricians continued to grow with the introduction of local anesthetic and suture material and as a result of advocacy for its performance by two obstetricians, Delee and Pomeroy (Maier, 1997).The rationale for its use depends largely on the need to minimize the risk of severe, spontaneous, maternal trauma and to speed up delivery, if there is fetal distress. De Oliverial and Miquilini (2005) conducted exploratory study to identify the frequency and indication of episiotomy, interviewed with 12 doctors and 12 nurses who attend women giving birth at the Sao Paulo's Hospital. They suggested that episiotomy was performed in $76.2 \%$ of the normal births; the most frequent indications were; perineal rigidity $(28.7 \%)$, primiparity $(23.7 \%)$, macrosomic infant $(11.9 \%)$ and prematurity $(10.2 \%)$.

Episiotomy is performed in $60 \%$ of all deliveries in the United States and in a much higher percent of primigravidas (Thacker, 1983). Trauma is repaired as soon as possible after delivery to secure haemostasis. The immediate maternal outcomes of episiotomy include severity of perineal laceration, pain, and delayed wound healing. When the episiotomy tissue injury occurs, inflammation ensues. During the inflammatory process, cells that were destroyed by the trauma of incision or laceration release chemical agents that cause pain. These substances, histamine and plasmakinins, are liberated by the damaged tissue. As a result, the local blood flows and permeability of the capillaries increases, local extra cellular edema results, and producing pain by causing pressure in the surrounding tissues. Pain management is considered as an important part of care that the American

Volume 6 Issue 12, December 2017 


\section{International Journal of Science and Research (IJSR) \\ ISSN (Online): 2319-7064}

Index Copernicus Value (2016): 79.57 | Impact Factor (2015): 6.391

Pain Society coined the phrase "Pain:the 5th vital sign" (Camphell, 1995) to emphasize its significance and to increase the awareness among health care professionals on the importance of effective pain assessment and management which is also mandated by the JCAHO (2003).

Episiotomy pain is an unpleasant sensory and emotional experience associated with tissue damage. It disables and distresses more people than any single disease. Mothers describe an acute pain during the first two weeks following childbirth. The most commonly used words are hot, sore, throbbing, aching and stinging. Perineal discomfort, pain and delayed wound healing from episiotomy continue to be a problem for many postpartum women. Wound healing is the process of tissue regeneration that completely restores structure and function of an injured area (Smeltzer, 2005). Episiotomy pain relief and also wound healing constitute best practice for post-partum perineal wound management. Recommendations based on available levels of evidence include a careful emphasis on both pharmacological approach and non-pharmacological approach. These approaches are selected on the basis of the patient's requirements and goals. Appropriate analgesic medications are used as prescribed. They are considered a last resort to be used only when other pain relief measures fail. Any intervention is most successful if initiated before pain sensitization occurs, and greater success is usually achieved if several interventions are applied simultaneously.

Although pain medication is the most powerful pain relief tool available to nurse, it is not the only one. Non pharmacologic nursing activities can assist in relieving pain with usually low risk to the patient. Combining non pharmacological interventions with medication may be the most effective way to relieve pain and improve the wound healing pattern. Non pharmacological approaches such as perineal care, infrared rays, relaxation techniques, sitz bath and cryotherapy are needed in addition to the regular medication. Cryotherapy is defined as cooling of definitive parts of the body by means of ice packs, ice cubes, ice water or ethylchloride sprays. It is used in the treatment of a range of conditions such as soft tissue lesions, arthritis, edema and pain (Fialka, 1994).

A frequent problem sustained after child birth is trauma which usually takes the form of the tear or surgical incision called episiotomy. It is one of the commonest surgical procedures in the world. Due to the episiotomy, women suffer with many problems, especially pain for several days, often in silence. Norrk (1991) compared different perineal outcomes on tissue healing between 181 women with episiotomies and 186 women without episotomies. The results showed better perineal healing among women without episiotomies than women with episiotomies and hence, this reveals that women with episiotomies need increased attention and care. Moreover, in our country, the postnatal care is not considered important when compared to antenatal care, as a focus shift from mother to baby occurs.

The investigator in her clinical experience noticed many mothers breast feed their new born in lying position during immediate postnatal period. Educating them to adequately adhere to the correct position failed and resulted only in noncompliance because of severe pain and swelling in the episiotomy wound. Mothers could not sit for a long time, due to pricking, throbbing pain and also suffered with sleep disturbance, discomfort, difficulty in walking and also inability to perform their self-care activities. Wound infection, gaping and swelling in the episiotomy wound are often manifested problems due to episiotomy non healing. Very often mothers requested to do something to reduce pain, even after they receive pain medication and routine care. Pain experience of the mother has a marked effect on women's wellbeing. So episiotomy pain relief and wound healing becomes a priority for a midwife in the postnatal period.

Midwives can play an important role in the care of perineal wounds following childbirth as wide variety of practices are carried out in this area, namely, pharmacological measures like pain medication and suppositories, and nonpharmacological measures like hot and cold applications, sitz bath, infrared rays, aroma therapy and cryotherapy. Realization of the relevance of care and potential impact both positive and negative of these interventions may have is important. Many researchers have highlighted that many practices relating to perineal care remain un-researched and therefore the need for evaluation is urgent.

Maintenance of effective pain relief must be balanced with the need to promote wound healing. It is important that midwives must recoginze the need for research - based practice. Application of ice pack on the episiotomy wound results in initial vasoconstriction, which is followed by a vasodilatation that will increase circulation and promote healing. (Low and Reed, 2000). A study compared three topical analgesic agents such as Epifoam, Hamamelis water and ice pack in the treatment of post episiotomy pain, All three agents were equally effective on the first day. Ice therapy had better pain relief thereafter (Moore and James 1989). Cryotherapy causes vasoconstriction and decreases exudative inflammations and edema. In addition, it saves enzyme and immune activity at the cells levels and increases regenerative process in tissues. (Despodova, Tsenov, et al 1995). Saeki (2002) conducted a study to determine the effect of application of cold or heat on pricking pain. The results suggest that cold promotes relief of pricking pain sensation and also suppresses autonomous responses compared to heat which has no such effect. The interventions recommended for women must comply with their economic status. The interventions chosen for women with episiotomies should also be of low cost, easily accessible and available at anytime and anywhere. Cold application is an analgesic therapy which is readily available in hospital and at home and is certainly cost effective. Moreover in today's fast paced life, early discharge has become the practice of the day. Postnatal mothers are discharged on day 1 to day 3 based on hospital policies. It is vital that intervention carried out in the hospital needs to be continued at home by the mother. Participation in her self-care, empowers the mother and equips her with decision making capacities. Application of ice pack seems to be feasible approach to be continued even after discharge.

\section{Volume 6 Issue 12, December 2017}




\section{International Journal of Science and Research (IJSR) \\ ISSN (Online): 2319-7064}

Index Copernicus Value (2016): 79.57 | Impact Factor (2015): 6.391

The application of ice packs to the perineum appears to give short term pain relief by numbing the superficial tissue surrounding the injury and by its action on local nerve fibers (Hill, 1981). The prolonged exposure of the skin to cold results in reflex vasodilation, so the desired temperature of $10-15$ o $\mathrm{C}\left(59^{\circ} \mathrm{F}\right)$ for $15-20$ minutes, works out as effective therapy. Hence, the investigator has recognized cold therapy as a suitable technique for the newly delivered women with episiotomy, who finds that the problem of episiotomy pain interferes with her efforts to care for her baby and causes discomfort. A frequent problem sustained after child birth is trauma which usually takes the form of the tear or surgical incision called episiotomy. It is one of the commonest surgical procedures in the world. Due to the episiotomy, women suffer with many problems, especially pain for several days, often in silence. Norrk (1991) compared different perineal outcomes on tissue healing between 181 women with episiotomies and 186 women without episotomies. The results showed better perineal healing among women without episiotomies than women with episiotomies and hence, this reveals that women with episiotomies need increased attention and care. Moreover, in India, the postnatal care is not considered important when compared to antenatal care, as a focus shift from mother to baby occurs.

The investigator in her clinical experience noticed many mothers breast feed their new born in lying position during immediate postnatal period. Educating them to adequately adhere to the correct position failed and resulted only in noncompliance because of severe pain and swelling in the episiotomy wound. Mothers could not sit for a long time, due to pricking, throbbing pain and also suffered with sleep disturbance, discomfort, difficulty in walking and also inability to perform their self-care activities. Wound infection, gaping and swelling in the episiotomy wound are often manifested problems due to episiotomy non healing. Very often mothers requested to do something to reduce pain, even after they receive pain medication and routine care. Pain experience of the mother has a marked effect on women's wellbeing. So episiotomy pain relief and wound healing becomes a priority for a midwife in the postnatal period.

Midwives can play an important role in the care of perineal wounds following childbirth as wide variety of practices are carried out in this area, namely, pharmacological measures like pain medication and suppositories, and nonpharmacological measures like hot and cold applications, sitz bath, infrared rays, aroma therapy and cryotherapy. Realization of the relevance of care and potential impact both positive and negative of these interventions may have is important. Many researchers have highlighted that many practices relating to perineal care remain un-researched and therefore the need for evaluation is urgent. Maintenance of effective pain relief must be balanced with the need to promote wound healing. It is important that midwives must recoginze the need for research - based practice. Application of ice pack on the episiotomy wound results in initial vasoconstriction, which is followed by a vasodilatation that will increase circulation and promote healing. (Low and Reed, 2000).
A study compared three topical analgesic agents such as Epifoam, Hamamelis water and ice pack in the treatment of post episiotomy pain, all three agents were equally effective on the first day. Ice therapy had better pain relief thereafter (Moore and James 1989). Cryotherapy causes vasoconstriction and decreases exudative inflammations and edema. In addition, it saves enzyme and immune activity at the cells levels and increases regenerative process in tissues. (Despodova, Tsenov, et al 1995). Saeki (2002) conducted a study to determine the effect of application of cold or heat on pricking pain. The results suggest that cold promotes relief of pricking pain sensation and also suppresses autonomous responses compared to heat which has no such effect.

The interventions recommended for women must comply with their economic status. The interventions chosen for women with episiotomies should also be of low cost, easily accessible and available at anytime and anywhere. Cold application is an analgesic therapy which is readily available in hospital and at home and is certainly cost effective. Moreover in today's fast paced life, early discharge has become the practice of the day. Postnatal mothers are discharged on day 1 to day 3 based on hospital policies. It is vital that intervention carried out in the hospital needs to be continued at home by the mother. Participation in her selfcare, empowers the mother and equips her with decision making capacities. Application of ice pack seems to be feasible approach to be continued even after discharge. The application of ice packs to the perineum appears to give short term pain relief by numbing the superficial tissue surrounding the injury and by its action on local nerve fibers (Hill, 1981). The prolonged exposure of the skin to cold results in reflex vasodilation, so the desired temperature of $10-15 \mathrm{o} \mathrm{C}\left(59^{\circ} \mathrm{F}\right)$ for 15-20 minutes, works out as effective therapy. Hence, the investigator has recognized cold therapy as a suitable technique for the newly delivered women with episiotomy, who finds that the problem of episiotomy pain interferes with her efforts to care for her baby and causes discomfort.

\section{Methodology}

\subsection{Research Approach}

Evaluatory research approach was considered to be the most appropriate to achieve the set objectives.

\subsection{Research Design}

The research design selected for the study was quasi experimental design which consists of manipulation and control but lacks randomization.

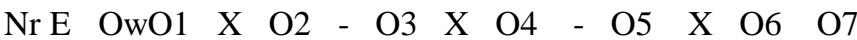

$\mathrm{X}$ O8 O9 X O10 Opw

$\begin{array}{llllll}\mathrm{Nr} C & \mathrm{OwO} 1 & \mathrm{O} 2 & -\mathrm{O} 3 & \mathrm{O} 4 & -\mathrm{O} 5\end{array}$

O7 $\quad 08$ O9 $\quad 010$ Opw

Keys

$\mathrm{Nr}$ - Non Randomization

E - Experimental group (mothers who received cryotherapy)

C - Control group (mothers who received routine care)

Volume 6 Issue 12, December 2017

www.ijsr.net

Licensed Under Creative Commons Attribution CC BY 


\section{International Journal of Science and Research (IJSR) \\ ISSN (Online): 2319-7064}

Index Copernicus Value (2016): 79.57 | Impact Factor (2015): 6.391

Owרר - Observation of episiotomy wound healing

O1 - Observation of episiotomy pain perception

$X$ - Application of ice pack

O2 - Observation of episiotomy pain perception immediately, 1 hour and 2 hour, after the1st sitting.

O3 - Observation of episiotomy pain perception before 2nd sitting.

O4 - Observation of episiotomy pain perception immediately, 1 hour and 2 hour after the 2 nd sitting

O5 - Observation of episiotomy pain perception before the 3rd sitting.

O6 - Observation of episiotomy pain perception immediately, 1 hour and 2 hour after the 3rd sitting.

O7 - Observation of episiotomy pain perception before the 4th sitting.

O8 - Observation of episiotomy pain perception immediately, 1 hour and 2 hour after the 4th sitting.

O9 - Observation of episiotomy pain perception before the 5th sitting.

O10 - Observation of episiotomy pain perception immediately, 1 hour and 2 hour after the 5th sitting.

Opw - Observation of post episiotomy wound healing.

\subsection{Manipulation}

The application of ice packs covered with 4 layers of gauze, maintained at $15^{\circ}$ Cover the episiotomy wound applied for 15 minutes for 5 sittings with the 1st sitting given 6 hours after delivery followed by 2 more sittings given an interval of 6 hours interval in the next 2 consecutive days. Routine perineal care after each sitting was provided.

\subsection{Control}

To abide by the ethical principles routine perineal care, 2 times daily, 6 hourly interval, as prescribed by hospital policy was permitted for mothers in the control group.

\subsection{Variables}

Independent variable in this study was cryotherapy; dependent variables were pain and wound healing.

\subsection{Setting}

The study was conducted in postnatal ward, new block at Sri Ramachandra Hospital, Porur. It is an educational institution with 1675 beds. The postnatal ward situated in the 3rd floor, is an exclusive area allocated to women and children. The postnatal ward consists of 40 beds where the postnatal care is provided.

\subsection{Population}

Mothers who had normal vaginal delivery with episiotomy.

\subsection{Sample}

Mothers who had spontaneous vaginal delivery within the period of study and who fulfilled the inclusion and exclusion criteria.

\subsection{Sample size}

Sample comprised of 40 mothers with episiotomy, 20 mothers in experimental group and 20 mothers in control group.

\subsection{Criteria used for selection of samples}

\subsubsection{Inclusion Criteria}

a) All mothers who underwent normal vaginal delivery with mediolateral episiotomy measuring $2.5-3 \mathrm{~cm}$.

b) All primiparous mothers.

c) Mothers willing to participate in the study

\subsection{Exclusion criteria}

a) Mothers with assisted delivery.

b) Mothers with associated complications

c) Mothers with extended episiotomy

d) Mothers who delivered between 2 pm to 12 midnight.

e) Mothers who had early rupture of membrane.

\subsection{Tool and Scoring}

The tool consists of 3 parts.

\subsubsection{Part A}

It consists of demographic data, such as age, education, occupation, family income, habitance and clinical data that includes height, weight, body mass index and haemoglobin.

\subsubsection{Part B}

It consists of 10 point Numeric pain intensity scale that was used to assess the episiotomy pain. The scale comprised of a horizontal line with 0-10 numerical number. The score 0 indicates no pain and score 10 indicates worst possible pain. The pain scale was shown to mother prior and half an hour, 1 hour and 2 hour after the intervention and the results were marked with color code.

\subsubsection{Part C}

It consists of modified Davidson's REEDA scale. It consists of 5 components such as redness, edema, ecchymosis, discharge and approximation. Each component has 4 options. Each component has a score $0-4$. The total score was 20 . The scale was administered to the mothers who completed 6 hours after delivery. The first observation $(\mathrm{Ow})$ indicates the baseline data. The post observation (Opw) was done after the 5th sitting of cryotherapy.

\subsection{Validity and reliability}

Validity was obtained from medical and nursing experts. Standardized numeric pain intensity scale and standardized modified REEDA scale was used.

\subsection{Pilot study}

Pilot study was conducted at SRH postnatal ward of New Block to determine feasibility, practicability of the instruments. Permission was obtained from the Ethical committee and Head of the Department of Obstetrics and Gynecology. Consent from the participants was obtained.

\section{Volume 6 Issue 12, December 2017}

\section{www.ijsr.net}

Licensed Under Creative Commons Attribution CC BY 


\section{International Journal of Science and Research (IJSR) \\ ISSN (Online): 2319-7064}

Index Copernicus Value (2016): 79.57 | Impact Factor (2015): 6.391

The pilot study was conducted with 12 samples of mothers with episiotomy, 6 in experimental group and 6 in control group. Pilot study results showed a variation in pain perception between the primi and multiparous mothers. So modification was done after pilot study by including only primiparous mother and excluding multiparous mothers.

\subsection{Data collection procedure}

The main study was conducted at New Block Postnatal Ward of Sri Ramachandra hospital. During the data collection period the mothers who had spontaneous vaginal delivery with episiotomy were selected on the basis of sampling criteria. The investigator first introduced self and obtained consent from the selected samples, the purpose of interview and its importance were explained along with the reassurance given regarding confidentiality of the interview. The data collection procedure is depicted below.

Table 1: Data collection procedure

\begin{tabular}{|c|c|c|c|c|c|c|}
\hline \multirow[b]{2}{*}{ Sittings } & \multicolumn{2}{|c|}{ Pre assessment } & \multicolumn{2}{|c|}{ Intervention } & \multicolumn{2}{|c|}{ Post assessment } \\
\hline & Pain & $\begin{array}{l}\text { Woand } \\
\text { healing }\end{array}$ & Cryotherapy & $\begin{array}{c}\text { Perineal } \\
\text { care }\end{array}$ & $\begin{array}{c}\text { Pain } \\
\text { (immediate, } \\
1 \text { bour, \& } 2 \text { bour) }\end{array}$ & $\begin{array}{l}\text { Woesod } \\
\text { healing }\end{array}$ \\
\hline $\begin{array}{l}\text { Day 1-1" } \\
\text { sitting } \\
6 \text { hours affer } \\
\text { delivery }\end{array}$ & $\checkmark$ & $\checkmark$ & * & $\checkmark$ & $\checkmark$ & $=$ \\
\hline $\begin{array}{l}\text { Day } 2 \\
-2^{M} \text { sitting }\end{array}$ & $\gamma$ & - & * & $\checkmark$ & $\checkmark$ & - \\
\hline $\begin{array}{l}\text { Day } 2 \\
3^{\text {yd }} \text { sitting }\end{array}$ & $\checkmark$ & - & * & $\checkmark$ & $\checkmark$ & - \\
\hline $\begin{array}{l}\text { Day }{ }^{3} \\
-4^{4} \text { sitting }\end{array}$ & $\checkmark$ & - & * & $\checkmark$ & $\checkmark$ & - \\
\hline $\begin{array}{l}\text { Day } 3 \\
-5^{\text {th }} \text { sitting }\end{array}$ & $\checkmark$ & - & * & $\checkmark$ & $\checkmark$ & $\checkmark$ \\
\hline
\end{tabular}

\subsection{Plan for Data Analysis}

Table 2: Plan for data analysis

\begin{tabular}{|c|c|c|}
\hline Statistics & Methods & Description \\
\hline \multirow{2}{*}{$\begin{array}{c}\text { Descriptive } \\
\text { statistics }\end{array}$} & $\begin{array}{c}\text { Frequency, } \\
\text { percentage, } \\
\text { Mean and } \\
\text { standard } \\
\text { deviation. }\end{array}$ & $\begin{array}{c}\text { To assess demographic and clinical } \\
\text { variables of both groups }\end{array}$ \\
\hline \multirow{2}{*}{$\begin{array}{c}\text { Inferential } \\
\text { statistics }\end{array}$} & Paired 't' test & $\begin{array}{c}\text { To evaluate the effect of cryotherapy } \\
\text { on pain, wound healing among } \\
\text { mothers with episiotomy within the } \\
\text { groups. }\end{array}$ \\
\cline { 2 - 3 } & Student 't' test & $\begin{array}{c}\text { To compare the pain and wound } \\
\text { healing between the groups. }\end{array}$ \\
\cline { 2 - 3 } & ANOVA test & $\begin{array}{c}\text { To associate the pain, wound healing } \\
\text { with demographic variables, clinical } \\
\text { variables }\end{array}$ \\
\hline
\end{tabular}

\section{Results}

Table 3 depicts that 4 mothers (20\%) with episiotomy belong to the age group of equal or less than 20 years, majority of the mothers with episiotomy, $14(70 \%)$ belong to the age group of 21 to 25 years in experimental and control group. 2 mothers $(10 \%)$ with episiotomy belong to above 26 years group in both the experimental and control group. Considering the educational status, 7 mothers (35\%) with episiotomy in experimental group and $15(75 \%)$ in control group had completed high school education.

With respect to occupational status, 17 mothers (85\%) with episiotomy in experimental group and $20(100 \%)$ in control group were housewives. Regarding family income (per month), 9 mothers (45\%) with episiotomy in experimental group and $12(10 \%)$ in control group belong to an income group of Rs.2501 to 3000. 6 mothers (30\%) with episiotomy in experimental group and $8(40 \%)$ in control group belong to Rs. 1500 to 2500 range.

With regard to habitance, 14 mothers (70\%) with episiotomy were from urban area in both experimental and control group and remaining $6(30 \%)$ were from rural area in both groups.

Table 3: Frequency and Percentage of demographic variables among mothers with episiotomy in experimental and control group $(\mathrm{N}=40)$

\begin{tabular}{|c|c|c|c|c|}
\hline \multirow{2}{*}{$\begin{array}{c}\text { Demographic } \\
\text { Variables }\end{array}$} & \multicolumn{2}{|c|}{$\begin{array}{c}\text { Experimental Group } \\
\qquad(\mathrm{n}=\mathbf{2 0 )}\end{array}$} & \multicolumn{2}{|c|}{$\begin{array}{c}\text { Control Group } \\
(n=20)\end{array}$} \\
\hline & Frequency & Percentage & Frequency & Percentage \\
\hline $\begin{array}{l}\text { Age (years) } \\
\text { a. } \leq 20 \\
\text { b. } 21-25 \\
\text { c. }>26\end{array}$ & $\begin{array}{c}4 \\
14 \\
2\end{array}$ & $\begin{array}{l}20.0 \\
70.0 \\
10.0\end{array}$ & $\begin{array}{c}4 \\
14 \\
2\end{array}$ & $\begin{array}{l}20.0 \\
70.0 \\
10.0\end{array}$ \\
\hline $\begin{array}{l}\text { Education } \\
\text { b. Primary } \\
\text { c. High school } \\
\text { d. Secondary } \\
\text { e. College }\end{array}$ & $\begin{array}{l}5 \\
7 \\
3 \\
5\end{array}$ & $\begin{array}{l}25.0 \\
35.0 \\
15.0 \\
25.0\end{array}$ & $\begin{array}{c}2 \\
15 \\
3 \\
0\end{array}$ & $\begin{array}{c}10.0 \\
75.0 \\
15.0 \\
0\end{array}$ \\
\hline $\begin{array}{l}\text { Occupation } \\
\text { a. Housewife } \\
\text { b. Skilled } \\
\text { c. Unskilled } \\
\text { d. Professional }\end{array}$ & $\begin{array}{l}17 \\
2 \\
0 \\
1\end{array}$ & $\begin{array}{c}85.0 \\
10.0 \\
0 \\
5.0\end{array}$ & $\begin{array}{c}20 \\
0 \\
0 \\
0\end{array}$ & $\begin{array}{c}100.0 \\
0 \\
0 \\
0\end{array}$ \\
\hline $\begin{array}{l}\text { Family Income } \\
\text { (per month) } \\
\text { a.Rs.1500-2500 } \\
\text { b.Rs.2501-3500 } \\
\text { c.Rs. } 3501 \\
\text { \& above }\end{array}$ & $\begin{array}{l}6 \\
9 \\
5\end{array}$ & $\begin{array}{l}30.0 \\
45.0 \\
25.0\end{array}$ & $\begin{array}{c}8 \\
12 \\
0\end{array}$ & $\begin{array}{c}40.0 \\
60.0 \\
0\end{array}$ \\
\hline $\begin{array}{l}\text { Habitance } \\
\text { a. Rural } \\
\text { b. Urban }\end{array}$ & $\begin{array}{c}6 \\
14\end{array}$ & $\begin{array}{l}30.0 \\
70.0\end{array}$ & $\begin{array}{c}6 \\
14\end{array}$ & $\begin{array}{l}30.0 \\
70.0\end{array}$ \\
\hline
\end{tabular}

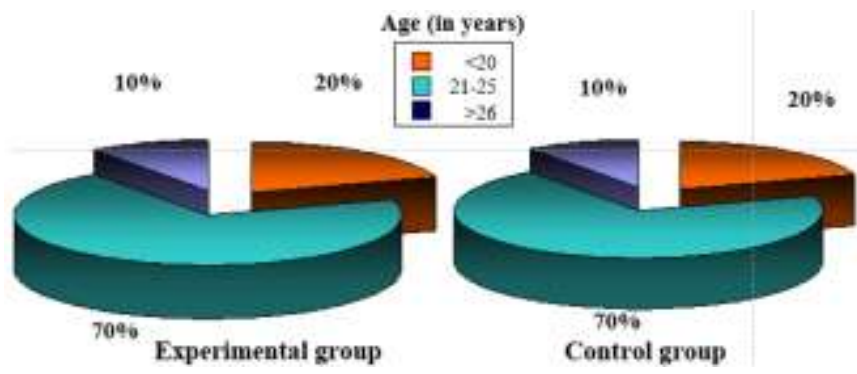

Figure 2: Percentage distribution of age in experimental and control group

\section{Volume 6 Issue 12, December 2017}




\section{International Journal of Science and Research (IJSR) \\ ISSN (Online): 2319-7064}

Index Copernicus Value (2016): 79.57 | Impact Factor (2015): 6.391
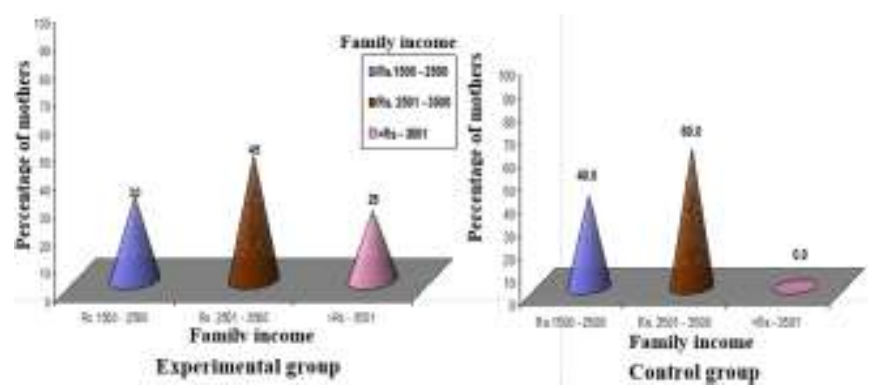

Figure 3: Percentage distribution of family income (per month) in experimental and control group

Table 4: Frequency and percentage of clinical variables among mothers with episiotomy in experimental and control group $(\mathrm{N}=40)$

\begin{tabular}{|c|c|c|c|c|}
\hline \multirow[t]{2}{*}{$\begin{array}{c}\text { Clinical } \\
\text { Variables }\end{array}$} & \multicolumn{2}{|c|}{$\underset{(n=20)}{\text { Experimental Group }}$} & \multirow{2}{*}{\multicolumn{2}{|c|}{$\begin{array}{c}\text { Control Group } \\
(n=20)\end{array}$}} \\
\hline & Frequency & Percentage & & \\
\hline $\begin{array}{l}\text { Body mass index } \\
\text { a. Normal weight } \\
\text { b. Over weight }\end{array}$ & $\begin{array}{c}20 \\
0\end{array}$ & $\begin{array}{r}100.0 \\
0\end{array}$ & 19 & \\
\hline Heamc & & & & \\
\hline & 9 & 45. & 11 & 55.0 \\
\hline b. 1 & 8 & 40 & 7 & 35.0 \\
\hline c. $12.1-13.0$ & 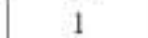 & 5.0 & 0 & 0 \\
\hline d. Above $13.1 \mathrm{gm}^{2} \%$ & 2 & 10.0 & 2 & 10.0 \\
\hline
\end{tabular}

Table 4 shows that the calculated body mass index all 20 $(100 \%)$ mothers with episiotomy in experimental group and 19 (95\%) mothers with episiotomy in control group fall in to normal category with the range of 19.8 to 20 . Only 1 mother with episiotomy in control group (5\%) was overweight falling into the body mass index range of 26.1-29. Pertaining to haemoglobin level, $9(45 \%)$ mothers in experimental group and $11(55 \%)$ in control group had a range of 10.0 to $11 \mathrm{gm} \%$.

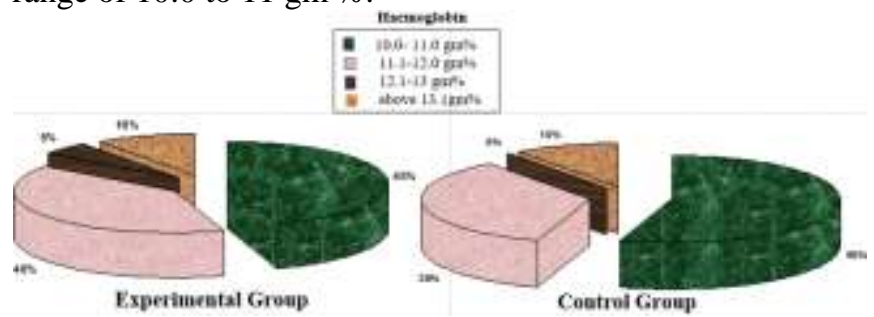

Figure 4: Percentage distribution of haemoglobin in experimental and control group

Table 5 shows that there was a highly significant difference between the preepisiotomy pain perception and post cryotherapy episiotomy pain perception in every sitting at a level of $\mathrm{p}<0.001$.This shows that cryotherapy was highly effective in reducing episiotomy pain perception in mothers with episiotomy.

The episiotomy pain perception showed a good reduction immediately after cryotherapy with a mean difference of 3.25 to 2.95 in every sitting. The mean difference of episiotomy pain perception reduced drastically in the first and second hour of the sitting.
Table 5: Mean difference, standard deviation and paired tvalue of episiotomy pain perception in experimental group.

\begin{tabular}{|c|c|c|c|c|}
\hline \multicolumn{5}{|c|}{$(n=20)$} \\
\hline Sitting & $\begin{array}{c}\text { Difference between } \\
\text { episiotomy pain } \\
\text { perception among } \\
\text { observations }\end{array}$ & $\begin{array}{c}\text { Mean } \\
\text { difference }\end{array}$ & $\begin{array}{l}\text { Standard } \\
\text { Deviation }\end{array}$ & $\begin{array}{l}\text { Paired } \\
\text { t-value }\end{array}$ \\
\hline \multirow[t]{3}{*}{1.} & Pre-immediate & 3.25 & 1.07 & $13.58^{\circ+4 *}$ \\
\hline & Pre-first hour & 1.95 & 0.89 & $9.83^{* * *}$ \\
\hline & Pre-second hour & 0.65 & 0.67 & $4.33^{* * * *}$ \\
\hline \multirow[t]{3}{*}{2.} & Pre-immediate & 3.20 & 0.41 & $34.87^{\circ+4}$ \\
\hline & Pre-first hour & 2.20 & 0.41 & $23.97^{* * 4}$ \\
\hline & Pre-second hour & 1.20 & 0.52 & $10.26^{* 4 *}$ \\
\hline \multirow[t]{3}{*}{3.} & Pre-immediate & 3.20 & 0.77 & $18.64^{* * * *}$ \\
\hline & Pre-first hour & 2.25 & 0.79 & $12.79^{\circ *+*}$ \\
\hline & Pre-second hour & 1.35 & 0.49 & $12.34^{0+44}$ \\
\hline \multirow[t]{3}{*}{4.} & Pre-immediate & 2.95 & 0.51 & $25.85^{* * 4}$ \\
\hline & Pre-first hour & 2.10 & 0.55 & $16.99^{* * * 4}$ \\
\hline & Pre-second hour & 1.20 & 0.52 & $10.26^{* * *}$ \\
\hline \multirow[t]{3}{*}{5.} & Pre-immediate & 3.10 & 0.79 & $17.59=\$ 4$ \\
\hline & Pre-first hour & 2.30 & 0.92 & $11.14^{* * *}$ \\
\hline & Pre-second hour & 1.40 & 0.75 & $8.30^{* * *}$ \\
\hline
\end{tabular}

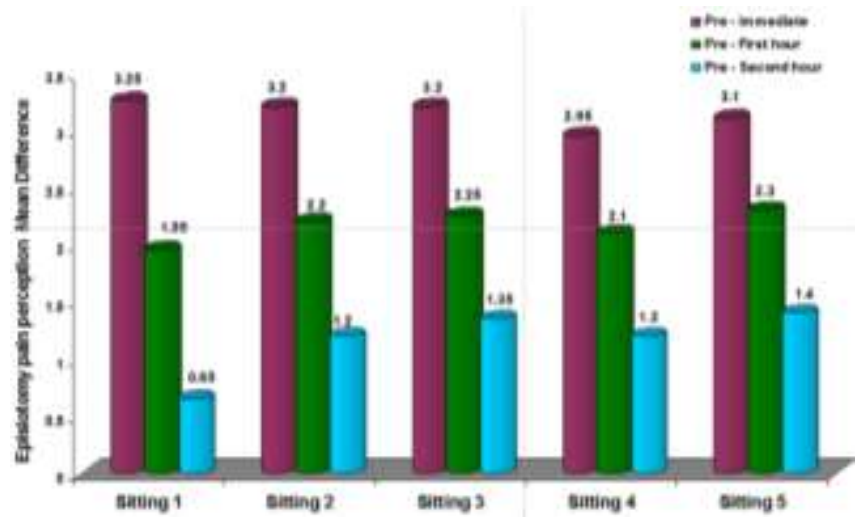

Figure 5: Episiotomy pain perception Mean difference score at different sittings in experimental group.

Table 6: Mean difference, standard deviation and paired tvalue of episiotomy pain perception in control group. $(\mathrm{n}=20)$

\begin{tabular}{|c|c|c|c|c|}
\hline Sitting & $\begin{array}{c}\text { Difference } \\
\text { between } \\
\text { episiotomy pain } \\
\text { perception } \\
\text { among } \\
\text { observations }\end{array}$ & $\begin{array}{c}\text { Mean } \\
\text { difference }\end{array}$ & $\begin{array}{l}\text { Standard } \\
\text { Deviation }\end{array}$ & $\begin{array}{l}\text { Paired } \\
\text { t-value }\end{array}$ \\
\hline \multirow[t]{3}{*}{ I. } & Pre-immediate & -0.60 & 0.50 & $5.34^{000}$ \\
\hline & Pre-first hour & 0.50 & 0.51 & $4,36 * 06$ \\
\hline & Pre-second hour & 0.30 & 0.73 & $1.83 \mathrm{NS}$ \\
\hline \multirow[t]{3}{*}{2.} & Pre-immediate & -0.85 & 0.37 & $10.38 \cdots$ \\
\hline & Pre-first hour & 0.50 & 0.51 & $4.36 * 00$ \\
\hline & Pre-second hout & 1.05 & 0.39 & $11.91^{\circ 60}$ \\
\hline \multirow[t]{3}{*}{3.} & Pre-immediate & -0.80 & 0.41 & $8.12 \cdot 0 \cdot$ \\
\hline & Pre-first hour & 1.10 & 0.64 & $7.68 * 00$ \\
\hline & Pre-second hour & 1.40 & 0.75 & $8.30^{+06}$ \\
\hline \multirow[t]{3}{*}{4.} & Pre-immediate & -0.80 & 0.52 & $6.89 \cdot 00$ \\
\hline & Pre-first hour & 1.20 & 0.41 & $13,08^{\circ \cdot 0}$ \\
\hline & Pre-second hour & 1.65 & 0.81 & $9.08 * 00$ \\
\hline \multirow[t]{3}{*}{5.} & Pre-immediate & -0.95 & 0.39 & $10.78^{\circ \cdot 00}$ \\
\hline & Pre-first hour & 1.15 & 0.59 & $8.76^{* 0 *}$ \\
\hline & Pre-second hour & 1.55 & 0.60 & $11.46^{\circ 60}$ \\
\hline
\end{tabular}

Volume 6 Issue 12, December 2017 www.ijsr.net 


\section{International Journal of Science and Research (IJSR) \\ ISSN (Online): 2319-7064}

Index Copernicus Value (2016): 79.57 | Impact Factor (2015): 6.391

Table 6 depicts that immediately after routine episiotomy care the episiotomy pain perception had increased for the mothers with episiotomy at a significant level of $p<0.001$ at every sitting. The mean difference ranged from -0.60 to 0.95 . But with first and second hour after routine episiotomy care, episiotomy pain perception had reduced significantly at a level of $p<0.001$ at every sitting. It was non-significant except for the second hour of the first sitting.

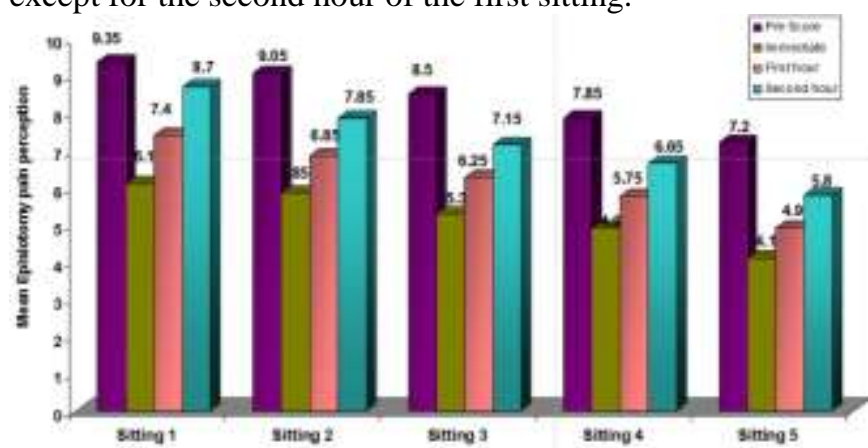

Figure 6: Mean Episiotomy pain perception at different sittings in experimental group

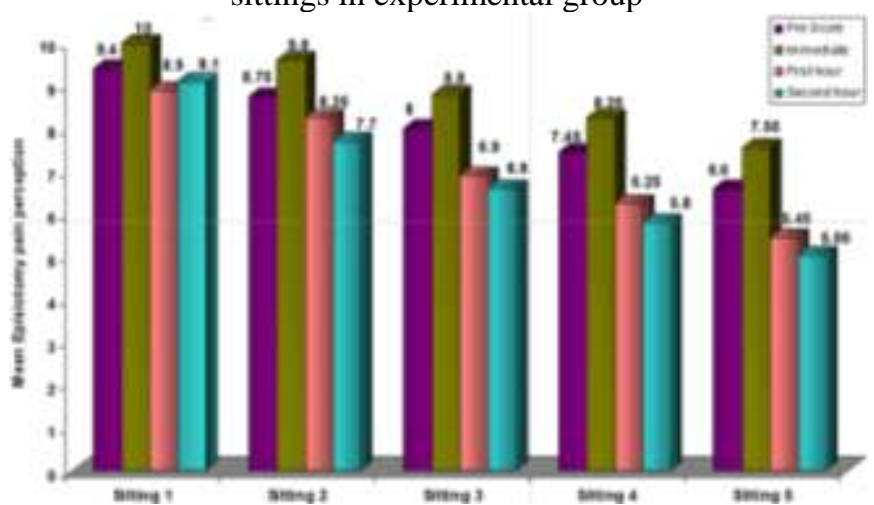

Figure 7: Mean Episiotomy pain perception at different sittings in control group

Table 7: Mean difference, standard deviation and paired tvalue of episiotomy wound healing in experimental and control group. $(\mathrm{N}=40)$

\begin{tabular}{|l|c|c|c|c|c|}
\hline \multirow{3}{*}{ Groups } & \multicolumn{3}{|c|}{ Episiotomy Wound Healing } & \multirow{2}{*}{ Scores } \\
\cline { 2 - 5 } & Pre-observation & Post observation & Paired \\
\cline { 2 - 5 } & Mean & $\begin{array}{l}\text { Standard } \\
\text { Deviation }\end{array}$ & Mean & $\begin{array}{c}\text { Standard } \\
\text { Deviation }\end{array}$ & \\
\hline $\begin{array}{l}\text { Experimental } \\
\text { Group(n=20) }\end{array}$ & 2.55 & 0.83 & 0.00 & 0.00 & $13.813^{*} * *$ \\
\hline $\begin{array}{l}\text { Control } \\
\text { Group(n=20) }\end{array}$ & 2.35 & 0.88 & 0.25 & 0.44 & $14.65^{* * *}$ \\
\hline$* * *$-p $<0.001$ & & & & & \\
\hline
\end{tabular}

Table 7 projects the pre and post wound healing scores observation. It shows highly significant difference at a level of $p<0.001$ in both experimental and control group. So both cryotherapy and routine episiotomy care help in effective wound healing.

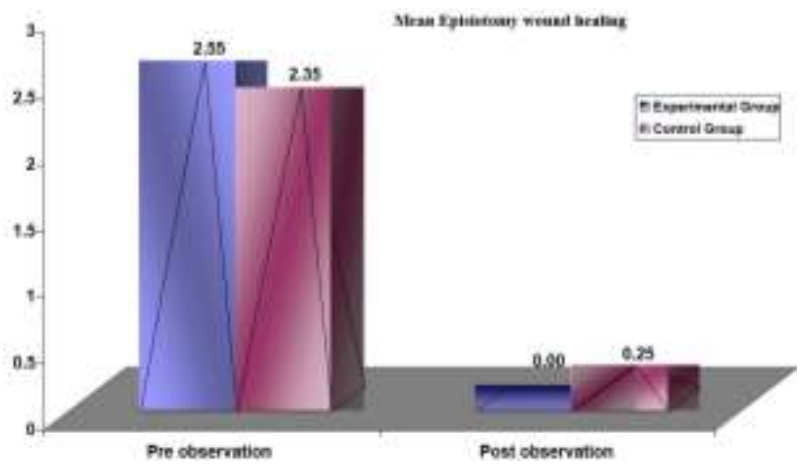

Figure 8: Mean Episiotomy wound healing at different sittings in experimental and control group.

Table 8 explains the comparison of episiotomy pain perception among mothers with episiotomy in experimental and control group immediately after cryotherapy and routine episiotomy care respectively. A significant level of pain perception reduction at $\mathrm{p}<0.001$ was seen among the mothers in experimental group. It signifies that cryotherapy is better compared to routine episiotomy care in reducing pain with regard to immediate effect.

Table 8: Mean difference, standard deviation and student tvalue of episiotomy pain perception between pre and immediate observations in experimental and control group.

\begin{tabular}{|c|c|c|c|c|c|}
\hline \multirow[b]{3}{*}{ Sittings } & \multicolumn{4}{|c|}{$(\mathrm{N}=40)$} & \multirow{3}{*}{$\begin{array}{l}\text { Student } \\
\mathrm{t} \text {-Value }\end{array}$} \\
\hline & \multicolumn{2}{|c|}{$\underset{(\mathbf{n}=\mathbf{2 0})}{\operatorname{Experimental} \text { group }}$} & \multicolumn{2}{|c|}{$\begin{array}{l}\text { Control group } \\
(\mathrm{n}-20)\end{array}$} & \\
\hline & $\begin{array}{c}\text { Mean } \\
\text { Difference }\end{array}$ & $\begin{array}{l}\text { Standard } \\
\text { Deviation }\end{array}$ & $\begin{array}{c}\text { Mean } \\
\text { Difference }\end{array}$ & $\begin{array}{l}\text { Standard } \\
\text { Deviation }\end{array}$ & \\
\hline 1. & 3.25 & 1.07 & -0.60 & 0.50 & $14.57^{* * *}$ \\
\hline 2. & 3.20 & 0.41 & 0.85 & 0.37 & $32.92^{* * * *}$ \\
\hline 3. & 3.20 & 0.77 & -0.80 & 0.41 & $20.55^{* 6 *}$ \\
\hline 4. & 2.95 & 0.51 & -0.80 & 0.52 & $22.94 * * *$ \\
\hline 5. & 3.10 & 0.79 & -0.95 & 0.39 & $20.56 * \%$ \\
\hline
\end{tabular}

Table 9 depicts the comparison of episiotomy pain perception among mothers with episiotomy in experimental and control group in the first hour after cryotherapy and routine episiotomy care respectively. A significant level of pain perception reduction at $\mathrm{p}<0.001$ was seen between the mothers in experimental and control group. It signifies that cryotherapy was better compared to routine episiotomy care in reducing pain perception during the first hour.

Table 10 depicts the comparison of episiotomy pain perception among mothers with episiotomy in experimental and control group second hour after cryotherapy and routine episiotomy care respectively. There was no significant difference in episiotomy pain perception between the mothers in experimental and control group. 


\section{International Journal of Science and Research (IJSR) \\ ISSN (Online): 2319-7064}

Index Copernicus Value (2016): 79.57 | Impact Factor (2015): 6.391

Table 9: Mean difference, standard deviation and student tvalue of episiotomy pain perception between pre and first hour observations in experimental and control group.

$$
(\mathrm{N}=40)
$$

\begin{tabular}{|c|c|c|c|c|c|}
\hline \multirow[b]{2}{*}{ Sittings } & \multicolumn{2}{|c|}{$\begin{array}{c}\text { Experimental group } \\
(\mathrm{n}=20)\end{array}$} & \multicolumn{2}{|c|}{$\begin{array}{c}\text { Control group } \\
(\mathrm{n}-20)\end{array}$} & \multirow[t]{2}{*}{$\begin{array}{l}\text { Student } \\
\text { t-Value }\end{array}$} \\
\hline & $\begin{array}{c}\text { Mean } \\
\text { Difference }\end{array}$ & $\begin{array}{l}\text { Standard } \\
\text { Deviation }\end{array}$ & $\begin{array}{c}\text { Mean } \\
\text { Difference }\end{array}$ & $\begin{array}{l}\text { Standard } \\
\text { Deviation }\end{array}$ & \\
\hline 1. & 1.95 & 0.89 & 0.50 & 0.51 & $6.34^{* 3 *}$ \\
\hline 2. & 2.20 & 0. & 0.50 & 0.51 & $11.57^{88 *}$ \\
\hline 3. & 2.25 & 0.79 & 1.10 & 0.64 & $5.07 \% 6$ \\
\hline 4. & 2.10 & 0.55 & 1.20 & 0.41 & $5.85^{* * *}$ \\
\hline 5. & 2.30 & 0.92 & 1.15 & 0.59 & $4.70 \neq \approx *$ \\
\hline
\end{tabular}

Table 10: Mean difference, standard deviation and student tvalue of episiotomy pain perception between pre and second hour observations in experimental and control group.

$$
(\mathrm{N}=40)
$$

\begin{tabular}{|c|c|c|c|c|c|}
\hline \multirow{2}{*}{ Settings } & \multicolumn{2}{|c|}{$\begin{array}{c}\text { Experimental } \\
\text { Group }(\mathrm{n}=20)\end{array}$} & \multicolumn{2}{c|}{$\begin{array}{c}\text { Control } \\
\text { Group }(\mathrm{n}=20)\end{array}$} & \multirow{2}{*}{$\begin{array}{c}\text { Student t- } \\
\text { value }\end{array}$} \\
\cline { 2 - 5 } & $\begin{array}{c}\text { Mean } \\
\text { Difference }\end{array}$ & $\begin{array}{c}\text { Standard } \\
\text { Deviation }\end{array}$ & $\begin{array}{c}\text { Mean } \\
\text { Difference }\end{array}$ & $\begin{array}{c}\text { Standard } \\
\text { Deviation }\end{array}$ & \\
\hline 1 & 0.65 & 0.67 & 0.3 & 0.73 & $1.58 \mathrm{NS}$ \\
\hline 2 & 1.2 & 0.52 & 1.05 & 0.39 & $1.02 \mathrm{NS}$ \\
\hline 3 & 1.35 & 0.49 & 1.4 & 0.75 & $0.25 \mathrm{NS}$ \\
\hline 4 & 1.2 & 0.52 & 1.65 & 0.81 & $1.95 \mathrm{NS}$ \\
\hline 5 & 1.4 & 0.75 & 1.55 & 0.6 & $.69 \mathrm{NS}$ \\
\hline
\end{tabular}

NS- Non Significant

Table 11: Mean difference, standard deviation and student t-

\begin{tabular}{|c|c|c|c|c|c|}
\hline \multirow{2}{*}{$\begin{array}{c}\text { Episiotomy } \\
\text { Wound } \\
\text { Healing } \\
\text { Scores }\end{array}$} & \multicolumn{2}{|c|}{$\begin{array}{l}\text { Experimental } \\
\text { Group }(n=20)\end{array}$} & \multicolumn{2}{|c|}{$\begin{array}{c}\text { Control } \\
\text { Group }(n=20)\end{array}$} & \multirow{2}{*}{$\begin{array}{l}\text { Student } \\
t-\text { Value }\end{array}$} \\
\hline & Mean & $\begin{array}{l}\text { Standard } \\
\text { Deviation }\end{array}$ & Mean & $\begin{array}{l}\text { Standard } \\
\text { Deviation }\end{array}$ & \\
\hline $\begin{array}{l}\text { Pre } \\
\text { Observation }\end{array}$ & 2.55 & 0.83 & 2.35 & 0.88 & $\begin{array}{l}0.74 \\
\text { N.S }\end{array}$ \\
\hline $\begin{array}{l}\text { Post } \\
\text { Observation }\end{array}$ & 0.00 & 0.00 & 0.25 & 0.44 & $2.517^{*}$ \\
\hline
\end{tabular}
value of episiotomy wound healing between experimental

Table 11 compares the effect of episiotomy wound healing between experimental and control group. The pre observation of episiotomy wound healing shows that there was no significant difference between the groups with't' 0.74 . The post episiotomy wound healing observation results shows that the post episiotomy wound healing was better with cryotherapy group at a significant level of $\mathrm{p}<0.05$.

Table 12: ANOVA of demographic and clinical variables with immediate episiotomy pain perception in first sitting for

\begin{tabular}{|c|c|c|c|c|}
\hline \multirow{2}{*}{$\begin{array}{l}\text { Demographic and } \\
\text { Clinical Variables }\end{array}$} & \multirow{2}{*}{$n$} & \multicolumn{2}{|c|}{$\begin{array}{l}\text { Immediate episiotomy } \\
\text { pain observation }\end{array}$} & \multirow{2}{*}{$\begin{array}{c}\text { ANOVA } \\
\text { Value }\end{array}$} \\
\hline & & $\begin{array}{c}\text { Mean } \\
\text { Difference }\end{array}$ & $\begin{array}{c}\text { Standard } \\
\text { Deviation }\end{array}$ & \\
\hline \multicolumn{5}{|l|}{ Age } \\
\hline a. $\leq 20$ & 4 & 3.25 & 0.95 & \multirow{3}{*}{0.056 N.S } \\
\hline b. $21-25$ & 14 & 3.21 & 1.19 & \\
\hline c. $>26$ & 2 & 3.50 & 0.71 & \\
\hline \multicolumn{5}{|l|}{ Education } \\
\hline a. Primary & 5 & 4.00 & 1.22 & \multirow{3}{*}{2.44 N.S } \\
\hline b. High school & 7 & 2.57 & 0.97 & \\
\hline c. Secondary & 3 & 3.00 & 1.00 & \\
\hline
\end{tabular}
experimental group. $(\mathrm{n}=20)$

\begin{tabular}{|l|c|c|c|c|}
\hline d. College & 5 & 3.60 & 0.55 & \\
\hline Occupation & & & & \\
a. Housewife & 17 & 3.17 & 1.13 & 0.52 N.S \\
b. Others & 3 & 3.67 & 0.57 & \\
\hline Family Income (per & & & & \\
month) & & & & \\
a. Rs. 1500 - 2500 & 6 & 2.83 & 1.17 & 1.1 N.S \\
b. Rs. 2501 - 3500 & 9 & 3.22 & 1.20 & \\
c. Rs. 3501 \& above & 5 & 3.80 & 0.45 & \\
\hline Habitance & 6 & & & \\
a. Rural & 1 & 2.17 & 0.98 & $15.49 * * *$ \\
b. Urban & 4 & 3.71 & 0.73 & \\
\hline Heamoglobin & & & & \\
a. 10.0-11.0 gm\% & 9 & 2.89 & 0.93 & 2.75 N.S \\
b. 11.1 - 12.0 gm\% & 8 & 3.87 & 0.83 & \\
c. 12.1 \& above & 3 & 2.67 & 1.53 & \\
\hline
\end{tabular}

Table 12 projects that there was no significant association between the demographic and clinical variables with immediate episiotomy pain perception in first sitting, except with regard to habitance which has highly significant association at a level of $\mathrm{p}<0.001$. Mothers from urban area has higher mean pain difference $3.71 \pm 0.73$ than mothers from rural area $2.17 \pm 0.98$.

Table 13 explains that there was significant association between habitance and first hour episiotomy pain perception in first sitting among mothers with episiotomy of experimental group at a level of $\mathrm{p}<0.05$. Also significant association was found between education and first hour episiotomy pain perception in first sitting in experimental group at a level of $\mathrm{p}<0.01$.

Table 14 indicates that there was no significant association between the demographic and clinical variables with episiotomy healing for experimental group.

Table 13: ANOVA of demographic and clinical variables with first hour episiotomy pain perception in first sitting for

\begin{tabular}{|c|c|c|c|c|}
\hline \multirow{2}{*}{$\begin{array}{l}\text { Demographic and } \\
\text { Clinical Variables }\end{array}$} & \multirow{2}{*}{$\mathbf{n}$} & \multicolumn{2}{|c|}{$\begin{array}{c}\text { First hour episiotomy } \\
\text { pain observation }\end{array}$} & \multirow{2}{*}{$\begin{array}{c}\text { ANOVA } \\
\text { Value }\end{array}$} \\
\hline & & $\begin{array}{c}\text { Mean } \\
\text { Difference }\end{array}$ & \begin{tabular}{|l|} 
Standard \\
Deviation
\end{tabular} & \\
\hline $\begin{array}{l}\text { Age (years) } \\
\text { a. } \leq 20 \\
\text { b. } 21-25 \\
\text { c. }>26\end{array}$ & \begin{tabular}{|c|}
4 \\
14 \\
2 \\
\end{tabular} & $\begin{array}{l}2.25 \\
1.86 \\
2.00\end{array}$ & $\begin{array}{l}0.96 \\
0.95 \\
0.00\end{array}$ & 0.28 N.S \\
\hline $\begin{array}{l}\text { Education } \\
\text { a. Primary } \\
\text { b. High school } \\
\text { c. Secondary } \\
\text { d. College }\end{array}$ & $\begin{array}{l}5 \\
7 \\
3 \\
5 \\
\end{array}$ & $\begin{array}{l}4.00 \\
2.57 \\
3.00 \\
3.60\end{array}$ & $\begin{array}{l}0.71 \\
0.75 \\
0.58 \\
0.00\end{array}$ & $7.75^{* *}$ \\
\hline $\begin{array}{l}\text { Occupation } \\
\text { a. Housewife } \\
\text { b. Others }\end{array}$ & $\begin{array}{c}17 \\
3\end{array}$ & $\begin{array}{l}1.94 \\
2.00\end{array}$ & $\begin{array}{l}0.97 \\
0.00\end{array}$ & 0.01 N.S \\
\hline $\begin{array}{l}\text { Family Income } \\
\text { (per month) } \\
\text { a. Rs. } 1500-2500 \\
\text { b. Rs. } 2501-3500 \\
\text { c. Rs. } 3501 \text { \& above }\end{array}$ & $\begin{array}{l}6 \\
9 \\
5 \\
\end{array}$ & $\begin{array}{l}2.00 \\
1.89 \\
2.00 \\
\end{array}$ & $\begin{array}{l}1.09 \\
1.05 \\
0.00 \\
\end{array}$ & 0.04 N.S \\
\hline $\begin{array}{l}\text { Habitance } \\
\text { a. Rural } \\
\text { b. Urban }\end{array}$ & $\begin{array}{c}6 \\
14 \\
\end{array}$ & $\begin{array}{l}1.33 \\
2.21\end{array}$ & $\begin{array}{l}0.52 \\
0.89\end{array}$ & $5.02 *$ \\
\hline $\begin{array}{l}\text { Heamoglobin } \\
\text { a. } 10.0-11.0 \mathrm{gm} \% \\
\text { b. } 11.1-12.0 \mathrm{gm} \% \\
\text { c. } 12.1 \& \text { above }\end{array}$ & $\begin{array}{l}9 \\
8 \\
3\end{array}$ & $\begin{array}{l}1.89 \\
2.12 \\
1.67\end{array}$ & $\begin{array}{l}0.78 \\
1.12 \\
0.58\end{array}$ & 0.31 N.S \\
\hline
\end{tabular}
experimental group. $(n=20)$

Volume 6 Issue 12, December 2017 


\section{International Journal of Science and Research (IJSR) \\ ISSN (Online): 2319-7064}

Index Copernicus Value (2016): 79.57 | Impact Factor (2015): 6.391

Table 14: ANOVA of demographic and clinical variables with episiotomy wound healing for experimental group.

\begin{tabular}{|c|c|c|c|c|}
\hline \multirow{2}{*}{$\begin{array}{l}\text { Demographic and } \\
\text { Clinical Variables }\end{array}$} & \multirow{2}{*}{$\mathbf{n}$} & \multicolumn{2}{|c|}{\begin{tabular}{|l|} 
Episiotomy Wound \\
healing observation
\end{tabular}} & \multirow{2}{*}{$\begin{array}{c}\text { ANOVA } \\
\text { Value }\end{array}$} \\
\hline & & \begin{tabular}{|c|} 
Mean \\
Difference
\end{tabular} & \begin{tabular}{|l|} 
Standard \\
Deviation \\
\end{tabular} & \\
\hline $\begin{array}{l}\text { Age (years) } \\
\text { a. } \leq 20 \\
\text { b. } 21-25 \\
\text { c. }>26\end{array}$ & \begin{tabular}{|c|}
4 \\
14 \\
2 \\
\end{tabular} & $\begin{array}{l}2.00 \\
2.64 \\
3.00\end{array}$ & $\begin{array}{l}0.00 \\
0.93 \\
0.00\end{array}$ & 1.32 N.S \\
\hline $\begin{array}{l}\text { Education } \\
\text { a. Primary } \\
\text { b. High school } \\
\text { c. Secondary } \\
\text { d. College }\end{array}$ & $\begin{array}{l}5 \\
7 \\
3 \\
5\end{array}$ & $\begin{array}{l}2.40 \\
2.57 \\
2.67 \\
2.60\end{array}$ & $\begin{array}{l}1.14 \\
0.53 \\
0.58 \\
1.14\end{array}$ & 0.07 N.S \\
\hline $\begin{array}{l}\text { Occupation } \\
\text { a. Housewife } \\
\text { b. Others }\end{array}$ & $\begin{array}{c}17 \\
3\end{array}$ & $\begin{array}{l}2.65 \\
2.00\end{array}$ & $\begin{array}{l}0.78 \\
1.00\end{array}$ & 1.62 N.S \\
\hline $\begin{array}{l}\text { Family Income } \\
\text { (per month) } \\
\text { a. Rs. } 1500-2500 \\
\text { b. Rs. } 2501-3500 \\
\text { c. Rs. } 3501 \text { \& above }\end{array}$ & $\begin{array}{l}6 \\
9 \\
5\end{array}$ & $\begin{array}{l}2.67 \\
2.44 \\
2.60\end{array}$ & $\begin{array}{l}1.03 \\
0.53 \\
1.14\end{array}$ & 0.13 N.S \\
\hline $\begin{array}{l}\text { Habitance } \\
\text { a. Rural } \\
\text { b. Urban }\end{array}$ & \begin{tabular}{|c|}
6 \\
14 \\
\end{tabular} & $\begin{array}{l}3.00 \\
2.36 \\
\end{array}$ & $\begin{array}{l}0.63 \\
0.84\end{array}$ & 2.79 N.S \\
\hline $\begin{array}{l}\text { Heamoglobin } \\
\text { a. } 10.0-11.0 \mathrm{gm} \% \\
\text { b. } 11.1-12.0 \mathrm{gm} \% \\
\text { c. } 12.1 \& \text { above }\end{array}$ & $\begin{array}{l}9 \\
8 \\
3\end{array}$ & $\begin{array}{l}2.78 \\
2.38 \\
2.33 \\
\end{array}$ & $\begin{array}{l}0.83 \\
0.74 \\
1.15\end{array}$ & 0.60 N.S \\
\hline
\end{tabular}

NS - Non Significant

\section{Discussion}

The sample comprised of 40 mothers with episiotomy, 20 in the experimental and 20 in the control group. In both the experimental and control group, majority 14 of the mothers $(70 \%)$ were falling into the age group of $21-25$ years. With regard to occupational status, 17 mothers $(85 \%)$ with episiotomy in experimental group and 20(100\%) in control group were housewives. Considering family income (per month) 9 mothers (45\%) with episiotomy in experimental group and $12(10 \%)$ in control group belonged to an income group of Rs.2501 - 3500 .

In respect to habitance, 14 of the mothers (70\%) with episiotomy were from urban area in both the experimental and control group. Pertaining to education, 7 mothers (35\%) with episiotomy in experimental group and 15 mothers (75\%) with episiotomy in control group had completed high school education.

In clinical variables, all 20 mothers $(100 \%)$ with episiotomy in experimental group and 19 mothers (95\%) with episiotomy in control group were within the normal body weight category with the range of body mass index from 19.8 to 20.1 and 1 mother $(5 \%)$ with episiotomy was overweight with the range of body mass index from 26.1 to 29 in control group.

Regarding haemoglobin level, 9 mothers (45\%) with episiotomy in experimental group and 11 mothers $(55 \%)$ with episiotomy in control group had a range of $10-11 \mathrm{gm} \%$.
The frequency distribution of demographic variables such as age, occupation, family income and habitance and clinical variables such as body mass index and haemoglobin data among the two groups revealed that homogeneity was maintained in selection of samples. The study findings are discussed based on the objectives as follows.

The first objectives of the study was to evaluate the effect of cryotherapy on pain perception among mothers with episiotomy.

In experimental group and control group, the episiotomy pain perception was assessed through Numeric pain intensity scale.

In experimental group, episiotomy pain perception was observed before and immediately, first hour and second hour after cryotherapy for 5 sittings. There was a highly significant difference on episiotomy pain perception in experimental group at a level of $p<0.001$. It depicts that cryotherapy was highly effective in reducing episiotomy pain perception among mothers with episiotomy.

Cryotherapy had good effect on episiotomy pain perception immediately after its application with a mean difference of 3.25 to 2.95 in every sitting. Also a significant reduction of episiotomy pain perception during first and second hour following cryotherapy in every sitting was observed.

In control group, episiotomy pain perception was observed before and immediately, first hour and second hour after routine episiotomy care for 5 sittings.

Episiotomy pain perception had increased immediately following routine episiotomy care among mothers with episiotomy at a significant level of $p<0.001$ at every sitting. The mean difference ranged from -0.60 to -0.95 . It highlights that episiotomy pain perception was increased immediately following routine episiotomy care among mothers with episiotomy. But, with first and second hour after routine episiotomy care, episiotomy pain perception had reduced significantly at a level of $\mathrm{p}<0.001$ at every sittings. Except with second hour first sitting which was non-significant.

These results correlate with the study findings of Seeki (2002) who assessed the effect of local application of cold or heat for relief of pricking pain. Application of cold to the stimulation site using an ice water pack reduced blood flow and skin conductance level responses and pain sensation. On the other hand application of heat using a hot water bottle caused a significant increase in pain sensation and enhanced blood flow and skin conductance level responses

The second objective of the study was to evaluate the effect of cryotherapy on wound healing among mothers with episiotomy.

The rapidity in episiotomy wound healing was assessed twice before the first sitting and after the last sitting in both experimental group and control group respectively using modified REEDA scale.

\section{Volume 6 Issue 12, December 2017}




\section{International Journal of Science and Research (IJSR) \\ ISSN (Online): 2319-7064}

Index Copernicus Value (2016): 79.57 | Impact Factor (2015): 6.391

In experimental group there was a highly significant difference on episiotomy wound healing at a level of $\mathrm{p}<0.001$ with pre mean value of 2.55 with standard deviation of 0.83 and post mean value of 0.00 with Standard Deviation of 0.00 .

The control group also showed a highly significant difference on episiotomy wound healing at a level of $\mathrm{p}<0.001$ with pre mean value of 2.35 with standard deviation of 0.88 and post mean value of 0.25 with Standard Deviation of 0.44 .

The results highlights that both the cryotherapy and routine episiotomy care helped in wound healing. These findings confirms with the emphasis of Despodova, Tsenov, et al (1995) that cryotherapy caused vasoconstriction and decreased exudative inflammations and edema. In addition, it saved enzyme and immune activity at the cells levels and increased regenerative process in tissues.

The third objective of the study was to compare the pain perception and wound healing among mothers with episiotomy between the experimental and control groups.

Comparison of episiotomy pain perception between the experimental and control group showed highly significant difference in immediate and first hour following cryotherapy at a level of $p<0.001$, whereas in second hour there was no significant difference of episiotomy pain perception between the experimental and control groups.

The study findings conform with the findings of Ramler, (1986) who compared cold with warms sitz baths for relief of postpartum perineal among forty mothers. Mothers rated the degree of perineal pain before and after each sitz bath and at half - hour and one - hour intervals after each bath by using $0-5$ pain scale. The analysis of pain scale scores using a two - way analysis of variance with replications showed that cold sitz baths were significantly more effective in relieving perineal pain. The greatest amount of pain relief was experienced immediately after the cold sitz baths.

Experimental group had a mean of pre mean value of 2.25 with standard deviation of 0.83 and post mean value 0.00 with standard deviation of 0.00 . The control group had a pre mean value of 2.35 with standard deviation of 0.88 and post mean value 0.25 with standard deviation of 0.44 .

Comparison of episiotomy wound healing revealed significant difference between the experimental and control group at a level of $p<0.05$. The study findings supports with the findings of Despodova, Tsenov, et al (1995) used ice for treating episiotomies after labor. Among 324 young mothers of experimental group who received ice over episiotomies from 1 st puerperal day for 3 days and 254 young mothers of control group who received one cryoprophylaxis over episiotomies. Complications namely oedema, inflammation, or suppuration for the experimental group was found to be $5.55 \%$ and for the control group it was $9.45 \%$.

The experimental group had better wound healing than control group. Since control group continue with edema, redness over one or two suture of the episiotomy incision after routine care.

The fourth objective of the study was to associate the demographic and clinical variables with pain perception and wound healing among mothers with episiotomy in experimental group.

Association of demographic and clinical variables with pain perception and wound healing of mothers with episiotomy in experimental group was assessed using ANOVA.

The study results revealed that there was highly significant association between habitance and immediate episiotomy pain perception in first sitting among mothers with episiotomy of experimental group with demographic at a level of $p<0.001$. Similarly, it showed an association at a level of $\mathrm{p}<0.05$ with first hour episiotomy pain perception. Mothers from urban area had lesser pain perception than mothers from rural area.

The study results depicts that there was a significant association between education and first hour episiotomy pain perception in first sitting at a level of $\mathrm{p}<0.01$. Other demographic and clinical variables showed no significant association with episiotomy pain perception and wound healing

\section{References}

[1] Adele Pillitteri. (2003). Maternal and Child Health Nursing, care of the child bearing and child rearing family. (6th ed.). Philadelphia: Lippincott.

[2] Akan, M., Misirlioglu, A.,Yildrim, S.,Cakir, B.,Taylan, G. \& Akoz, T.(2003). Ice application to minimize pain in the split-thickness skin graft donar site. Aesthetic Plast Surg., Jul-Aug;27(4):305-7.

[3] Bobak, I.M., Lowdermilk, D.L., Jenson, M.D. \& Perry, S.E. (1995). Maternity Nursing. (4th ed.). Tokyo: Mosby.

[4] Cunningham. (1997). Williams Obstetrics. (20th ed.). Philadelphia: Appleton and Longe Publications.

[5] De Oliveira, S.M. \& Miquilini, E.C.(2005). Frequency and Criteria for the indication of episiotomy. Rev Esc Enferm USP, Sep; 39 (3): 288-95.

[6] Despodova, T.S., Tsenov, D.,Chamova, M., Popova, G. \& Garnizov. T.(1995). Experience in treating episiotomies after labor with ice. Akush Ginekol (Sofiia),; 34 (3): 26-7.

[7] Dimitrov, A., Tsenow, D. \& Ganeva, G. (2000).Causes for heali complications in episiotomy. Akush Ginekol (Sofiia).; 40(4): 17-20.

[8] Dutta, D.C. (2004). Text book of Obstetrics, Perinatology and Contraception. (6th ed.). Calcutta: Central Book Agency.

[9] Emily Stone McKinney, Susan Rowen James, Sharon Smith Murray \& Jean Weiler Ashwill. (2005). Maternal Child Nursing. (2nd ed.). United States of America: Elsevier Saunders.

[10] Facchinetti, F., Casini, ML., Costabile, L., Malavasi, B. \& Unfer, V.( 2005). Diclofenac pyrrolidine versus

Volume 6 Issue 12, December 2017

www.ijsr.net

Licensed Under Creative Commons Attribution CC BY 


\section{International Journal of Science and Research (IJSR) \\ ISSN (Online): 2319-7064}

Index Copernicus Value (2016): 79.57 | Impact Factor (2015): 6.391

Ketoprofen for the relief of pain from episiotomy: a randomized controlled trial. Acta Obstet Gynecol Scand, Oct; 84 (10): $951-5$.

[11]Fiaka, V. \& Ernst, E. (1994). Cryotherapy. Wien Meal Wochenschr. 144 (3): 42-4.

[12] Hedayati, H., Dodd, JM., Pearce, E., Hotham, N. \& Crowther, C.A.,(2004). Rectal analgesia for the relief of perrineal pain after childbirth: a randomized controlled trial of diclofenac suppositories. Bjog, Oct; 111 (10): 1059-64.

[13]Hill, D. \& Pamela. (1990). Effect of head and cold on the perineum after episiotomy Laceration. Journal of nurse midwifery, 18(10), 124-129.

[14]Hur, M.H. \& Han, S.H. (2004). Clinical trial of aromatherapy on postparturn mother's perineal healing. T aechan Kanho Hakhoe chi, Feb; 34 (1): 53 - 62.

[15] Lafoy, J. \& Geden, E.A. (1989). Post - episiotomy pain warm versus cold sitz baths. Obstet Gynecol Neonatal Nurs., 18: 399-403.

[16]Lam, K.W., Wong, H.S. \& Pun, T.C. (2006). The practice of episiotomy in pubic hospitals in Hong Kong. Hong Kong med J., Apr; 12 (2): 94 - 8.

[17] Langer. B. \& Minetti, A. (2006). Early and late complications of episiotomy. J Gynecol obstet Biol Reprod (Paris), Feb; 35.

[18] Larsson, P.G., Platz-Christensen, J.J., Bergman, B. \& Wallstersson, G. (1991). Advantage or disadvantage of episiotomy compared with spontaneous perineal laceration. Gynecol Obstet Invest.; 31 (4): 213 - 6.

[19] Lorenz, N., Nougtara, A. \& Garner, P. (1998). Episiotomy in Burkina Faso. Trop Doct., Ap; 28 (2): 83 -5 .

[20]Lorenzi, E.A. (1991). Relaxation: episiotomy incisional pain and over all discomfort. J. Adv Nurs., Jun; 16 (6): $701-9$.

[21] Low, J. \& Reed, A. (2000). Electrotherapy explained. Principles and practice. (3rd ed). Buller worth Heinemann: Oxford.

[22] Macarthur, A.J. \& Macarthur, C. (2004). Incidence, severity, and determinants of perineal pain after vaginal delivery: a prospective cohort study. Am J Obstet Gybecol, Oct 191 (4); 1199-204.

[23] Maier, J.S. \& Maloni, J.A. (1997). Nurse advocacy for selective versus routine episiotomy. J Obstet Gynecol Neonatal Nurs., Mar-Apr; 26(2): 156-61.

[24] Minassian, V.A., Jazayeri, A., Perien, A., Prien, S.D., Timmons, R.L. \& Stumbo, K., (2002). Randomized trial of lidocaine oinment versus placebo for the treatment of postpartum perineal pain. Obstet Gynecol, Dec;100(6):1239-43.

[25] Moore, W. \& James, D.K. (1989). A random trial of three topical analgesia agents in the treatment of episiotomy pain following instrumental deliveries. Journal of obstetrics and gynecology. 10 (1): 35 - 39.

[26] Nam, H.K. \& Park, Y.S. (1991). A study on comparisons of ice bag and heat lamp for the relief of perineal discomfort. Kanho Hakhoe Chi.; 21 (1): 27-40.

[27] Norr, K., McGuinness, M. \& Nacion, K. (1991). Comparison between different perineal outcomes on tissue healing. J Nurse Midwifery, May-Jun; 36 (3): $192-$ 8.
[28] Otoide, V.O., Ogbonmwan, S.M. \& Okonofua, E.F. (2000). Episiotomy in Nigeria. Int J Gynaecol Obstet., Jan; 68(1): $13-7$.

[29] Peter, E.A., Janssen, P.A., Grange, C.S. \& Douglas, M.J., (2001). Ibuprofen versus acetaminophen with codeine for the relief of perineal pain after childbirth: a randomized controlled trial. CMAJ, Oct 30;165(9):12039.

[30] Polit Deniso, F. \& Hungler Bernadette, P. (1995) Nursing Research Principle and Methods. (5th ed.). Philadelphia: J.B.Lippincott Company.

[31] Potter, P.A. \& Perry, A.G. (2005). Fundamentals of Nursing, (6th ed.). St. Louis: Mosby.

[32] Qian, X., Smith, H.,Liang, H.,Liang, J. \& Garner, P. (2006). Evidence-informed obstetric practice during normal birth in China: trends and influences in hospitals. BMC Health Serv Res., Mar 8;6:29.

[33] Rageth, J.C., Buerklen, A. \& Hirch, H.A. (1989). Late complications of episiotomy. Z Geburstshilfe Perinatol, Sep-Oct;193(5):233-7.

[34] Ramler, D. \& Roberts, J. (1986). A comparison of cold and warm sitz baths for relief of post - partum perineal pain. J obstet Gynecol Neonatal Nurs., 15: 471 - 9.

[35] Reeder, J. \& Sharson. (1989). Maternity Nursing. (15th ed.). Philadelphia: J.B Lippincott Company.

[36] Saeki, Y. (2002). Effect of local application of cold or heat for relief of pricking pain. Nurs Health Sci., Sep; 4 (3): $97-105$.

[37] Smeltzer C Suzenne. \& Brunda G bare., (2005). Brunner and Siddarth, Text book of Medical and Surgical Nursing. (10th ed.). Philadelphia: J.B. Lipincott Company.

[38] Sule, S.T. \& Shitti, S.O. (2003). Puerperal complications of episiotomies at Ahmadu Bello University Teaching Hospital, Zaria, Nigeria. East Afr Med J., Jul; 80 (7): 351-6.

[39] Thacker, S.B. \& Banata, H.D. (1983). Benefits and risks of episiotomy: an interpretative review of the English language literature, 1960-1980. Obstect Gynecol Surv., Jun; 38 (6): 322-38.

[40] Weber, A.M. \& Meyn, L. (2002). Episiotomy use in the United States, 1979-1997. Obstect Gynecol, Dec; 100 (6): $1177-82$.

[41] Wesley, L. \& Ruby. (1996). Nursing Theories and Models. (2nd ed.). Pennsylvania: Spring House Publication. 